\section{A wonderful sight to behold?}

James M. Jasper

American Ground Zero: The Secret Nuclear War. By Carole Gallagher. MIT Press: 1993. Pp. 422. \$50, £32.25.

Nuclear Energy and the Public. By Joop van der Pligt. Blackwell: 1993. Pp. 193. £35. Life Under A Cloud: American Anxiety About the Bomb. By Allan M. Winkler. Oxford University Press: 1993. Pp. 282. \$27.50.

ONE of my vivid childhood memories is of my mother filling large jars with water and labelling them "October, 1962". She placed these, along with a large stock of canned goods, in a small room in our basement. We also assembled a box of canned foodstuffs for me at my kindergarten, where all the children practised going into the basement and putting our heads between our knees. There, a few miles from the White House, the Cuban missile crisis was no joke. Because it is easy to exaggerate either the goofiness or the high anxiety of such pathetic attempts at civil defence, one is tempted to read all of postwar history as dominated dramatically by the nervous shadow of nuclear weapons.

There are different ways to assess just how nuclear fission has affected us all. Joop van der Pligt has written a socialpsychological monograph about public reactions to civilian nuclear energy. Allan Winkler presents a sweeping history of civilian and military nuclear energy in the United States. Carole Gallagher has compiled a moving book of photographs and recollections of dozens of people affected by the US government's atomic bomb tests during the 1950s. Singly and together, the three books provide an appalling picture of government arrogance.

Gallagher's book, American Ground Zero, leaves the reader in baffled outrage. More than 400 beautiful pages introduce us to diverse men and women affected by fallout from the US government's testing of nuclear weapons in the deserts of Nevada: employees at the test site, Mormons trained to obey authority, foot soldiers ordered to charge toward mushroom clouds, ordinary citizens who lived downwind of the tests, families whose members never seem to die of anything but cancer.

The book's quotations are an indictment of various forms of authority. Mormon leaders taught that the US constitution was divinely inspired, so many of their followers saw their radiation-related illnesses as God's punishment. A military chaplain reassured soldiers, many of whom returned from their post-explosion manoeuvres bleeding from the eyes and other orifices, that "there is no need to be worried, as the Army has taken all of the necessary precautions to see that we're perfectly safe here . . the fireball as it

ascends up into the heavens .... is a wonderful sight to behold." Scientific experts also share some of the blame, although Gallagher also sought out those who began to criticize government policies. But, of course, in the end the overwhelming blame rests with a succession of federal and state agencies that consist- ently misled the public about the dangers of radiation.

Gallagher fears that, as a nation, Americans have become unwilling to recognize the nuclear war that the US government has perpetrated against its own citizens. Her book will help us to see. But the effect is numbing. The bad guys are consistently bad, the victims modern-day Jobs. With relatively little political analysis or hope, we can almost believe, like the Mormons, that this is God's punishment.

Next to Gallagher's document of condemnation, Allan Winkler's history of American nuclear energy, Life Under $A$ Cloud, seems almost Panglossian. His polished, measured prose does not fully capture either the heroism of the atomic

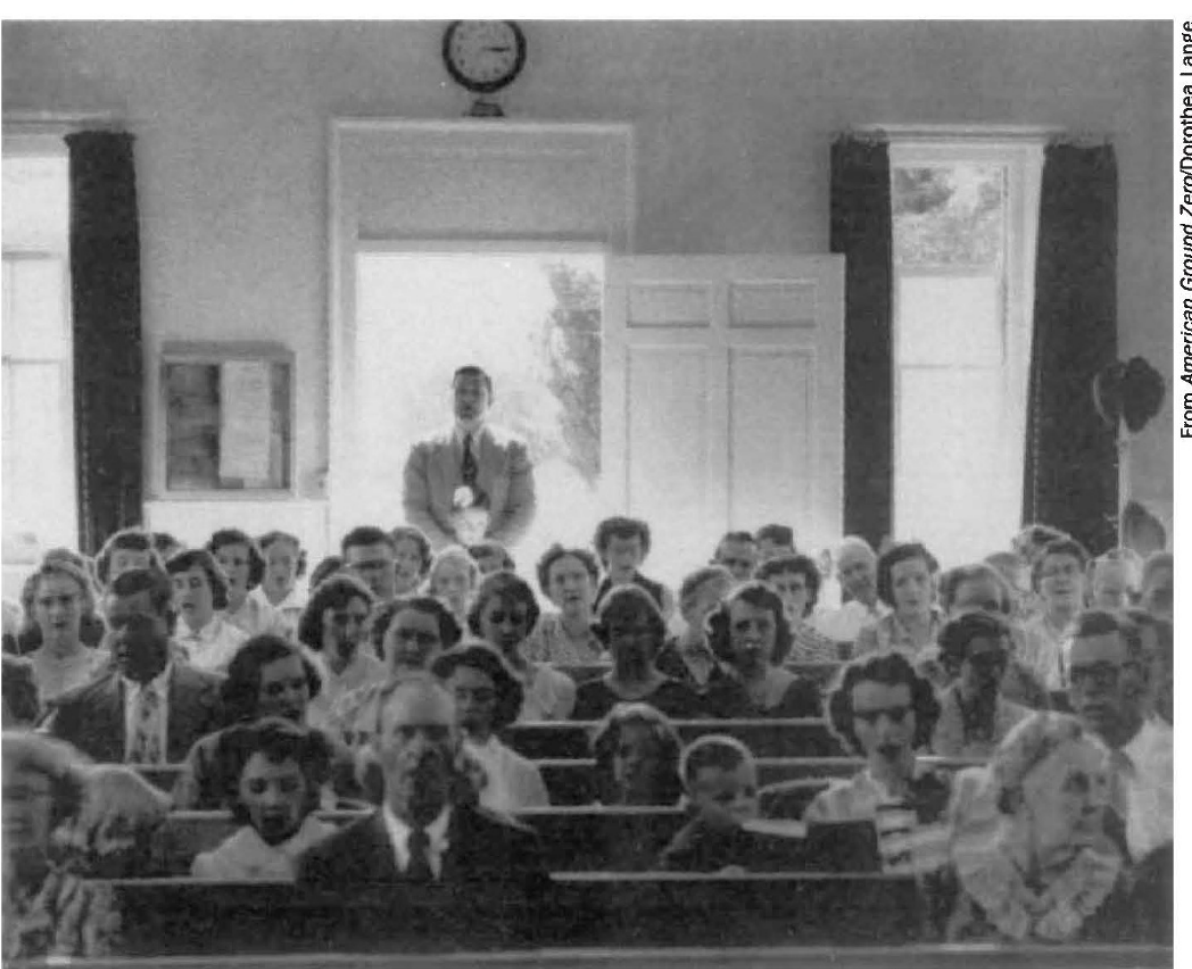

Blind faith - Mormons (Church of the Latter-day Saints) at Sunday worship, southern Utah, 1953. Top secret documents designated these people, who lived in the towns and villages around the atomic test site, as "a low-use segment of the population".

scientists who pulled off astounding scientific and technological feats or the arrogance of government decision-makers who stubbornly ignored risks and discounted the health of the public. Surprisingly, Gallagher's photojournalism has a richer texture than this book by a professional historian. Perhaps it was inevitable that a century of history in only 210 text pages should be superficial. But it need not have been bland, or marred by small and unsettling factual errors (for example, several people's occupations are misrepresented; James Conant is called the president of MIT, not Harvard).

Indeed, a short book of this scope could have been justified if it had a sharp analytical point, which this book lacks, beyond occasional references to scientists' participation in public debates. When he does try to summarize, Winkler sometimes even gets it wrong, for example, attributing the collapse of American civilian nuclear energy to the antinuclear movement and an increasing concern for safety, rather than to scandalous mismanagement and enormous cost increases.

Van der Pligt makes a serious effort to explain public attitudes, especially of those opposing it, towards civilian nuclear energy. In contrast to the Americans of Utah and Nevada whom Gallagher describes, large numbers of people (Americans and others) have regularly protested against military and civilian nuclear energy. Relying on social-psychological studies from around the world - Nuclear Energy and the Public is intended as a 
summary of this research - van der Pligt insists on the rationality of those suspicious of nuclear reactors, which exemplify risks that are invisible, involuntary, uncontrolled, uncertain, delayed and irreversible - all traits that inspire dread. This technology, it seems, had characteristics especially likely to make people nervous.

Studies of risk perception, initiated in the 1970 s partly to understand why members of the public could be so irrational as to reject nuclear energy, have contributed a great deal to our understanding of public opinion and attitude formation. But van der Pligt's discerning if plodding use of this literature retains a flaw from the cognitive psychology that long dominated risk studies: a blindness to the formal organizations and political contexts shaping attitudes. Other than the frequent "credibility problems" of government agencies - meaning that they often lie to the public - van der Pligt ignores the ways that democratic procedures matter to people, that nuclear programmes come to be associated with political parties and agendas, that attitudes are ways to take sides in public debates.

Van der Pligt's claim that the public is rational combines easily with the evidence provided by Gallagher and Winkler. That many citizens of the advanced industrial world distrust nuclear fission follows from the pugnacious way in which their governments have imposed it on them, an anxiety only reinforced by the technology's riskiness, itself long denied by those in power. Although many scientists have played important roles as independent critics since the 1940 s, more have allowed themselves to become tools of their governments' enthusiastic promotional activities. The public might be willing to take more risks if they thought they could believe what the experts and officials were telling them about those risks. But so far, they have little reason to do so.

James M. Jasper is in the Department of Sociology, New York University, New York, New York 10003, USA.

\section{From scientist to courtier}

\section{William R. Shea}

Galileo, Courtier: The Practice of Science in the Culture of Absolutism. By Mario Biagioli. University of Chicago Press: 1993. Pp. 402. £23.95, \$29.95.

A VISITOR from a distant galaxy arriving on Earth as scientists are busy filling in applications for research grants would form a peculiar idea of this delicate operation. Most scientists go through the exercise under duress, some in sullen silence, others in a stream of expletives. $\mathrm{He}$ would hear much about the waste of precious time and the arbitrariness, if not lunacy, of questions about the goal of their research, the equipment, methodology and technical support needed, and, last but not least, clearance from their ethics committee. He would discover scientists vetting friends' proposals to see how they will go down with the adjudicatory committee, and rumours might reach him of scientists offering to say a word in high places. He could not fail to notice that the pecking order in some disciplines is determined by the size of one's grant. On return to his galaxy, we would not be surprised if the visitor wrote an essay on terrestrial science in which grantsmanship figured prominently.

What an extraterrestrial had to say about our system of supporting research would be of the highest interest. Might he say of contemporary scientists what Biagioli says of Galileo? "The place of gifts within the logic of patronage explains the role of spectacular scientific produc- tion in Galileo's career. Galileo needed to produce or discover things that could be used as gifts for his patrons." Are twentieth-century scientists tempted to do work that yields tangible results, however secondary, instead of tackling fundamental problems whose solution may bring no immediate relief to man's estate and so fail to qualify for the largesse of funding authorities? We cannot discount the pressures of contemporary research they want becomes the research we want simply because there is no other way of carrying on. The marvel is that so many scientists are willing to pass up the big bucks in the hope of a big breakthrough.

Every society has its own system of benevolent or despotic patronage. It needed someone as gifted and knowledgeable as Mario Biagioli to explore the relationships between science and government in seventeenth-century Italy. No historians of the period will leave this book without having learned something about the Tuscan court or the Roman famiglia (as the popes called their own entourage). But will they be greatly enlightened about Galilean science and the birth of the scientific revolution? My guess is that they will have learned as much about Galileo's patronage. On occasion, the mechanics as our extragalactic visitor would know about condensed matter after a few days observing physicists cobbling together a grant proposal.

In fact, and Biagioli makes no bones about this, Galileo became a courtier (in the sense of having a court appointment) only when he was named "Philosopher and Chief Mathematician of the Grand Duke of Tuscany" in 1610. Galileo was then 46 years old and his best scientific work was behind him. Although his two main books, the Dialogue on the Two Chief World Systems: Ptolemaic and Copernican and the Two New Sciences were not published until 1632 and 1638, respectively, they were the fruits of his professorship at the University of Padua between 1592 and 1610. Galileo left the Venetian republic not to become a courtier in Florence but to have more time to arrange his material for publication. He wrote to the secretary of state of Tuscany on 7 May 1610: "If I could be repatriated, I would wish the Grand Duke to give me the leisure and the opportunity to draw my work to a conclusion without having to teach". Galileo got what he wanted: a professorship at the University of Pisa without obligation to give lectures or even reside in the city.

Biagioli recognizes that Galileo planned on enjoying the amenities of a research chair but argues that circumstances compelled him to change his role. The reader is invited to witness Galileo's "selffashioning" into a courtier and to realize

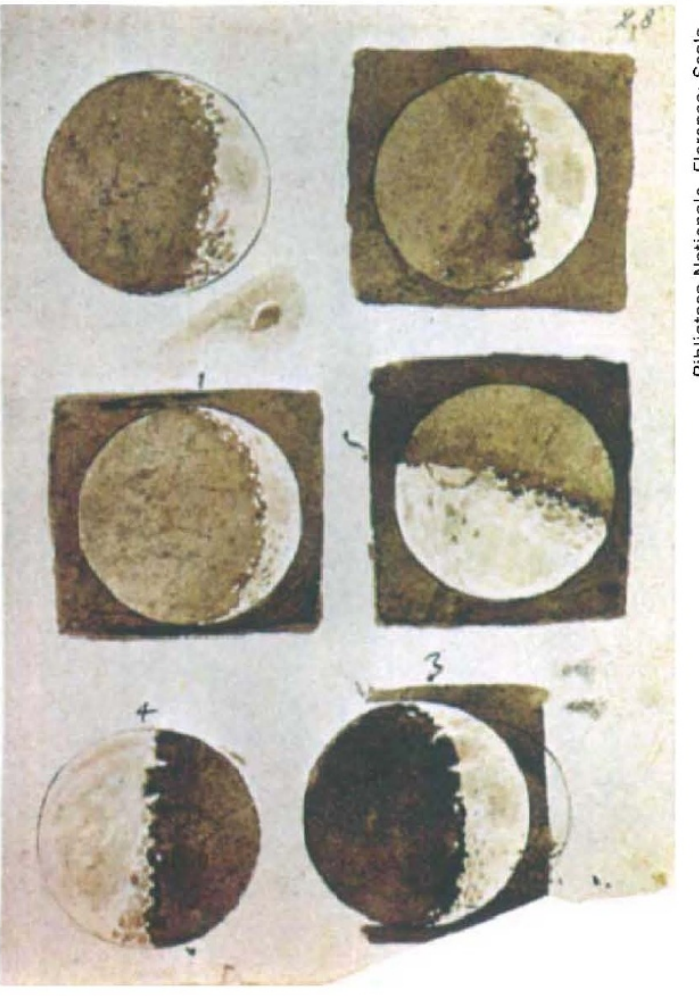

Galileo's sketches of the Moon pockmarked with mountains and craters, which were considered heretical for showing an imperfect heaven. 